\begin{tabular}{ccc}
\hline International Journal of Engineering \& Technology, $7\left(3.3^{\circ}\right)(2018) 65-67$ \\
SPC & Website: www.sciencepubco.com/index.php/IJET \\
Research paper & Technology \\
\hline
\end{tabular}

\title{
Analysis of Underground Lined Rock Cavern
}

\author{
I.V. Sharma ${ }^{1}$ and Dr. Pallavi Badry ${ }^{2}$
}

Assistant Professor, Department of Civil Engineering, Faculty of Science and Technology, ICFAI, Shankarpally, Hyderabad.

${ }^{2}$ Professor and Head, Department of Civil Engineering, Vidya Jyothi Institute of Technology, Hyderabad.

Email.id: pallavibadrim@vjit.ac.inAbstract-

\begin{abstract}
Underground storage excavation can be done either by access tunnel or by access shaft or the combinations of both. Other factors depend of land availability, surrounded by cavern site and also the depth of the cavern is the most important considerations. The caverns are generally built in rock where it offers the good support but need to analyze for the stress condition accurately. In this study the cavern along with the tunnel is analyzed for static analysis and the results are compared for both linear and nonlinear condition for the stage analysis. It has been found that the soil shows different stress condition with respect to special variation and the analysis method.
\end{abstract}

Keywords-cavern, tunnel with cavern, plastic analysis, boundary stresses

\section{Introduction}

Mined rock caverns are purpose-built underground spaces excavated in rock with access from vertical shafts or inclined drifts. These are mainly used store very large quantities of unrefined petroleum and natural gas. These are mostly constructed deep below ground level. For this purpose the rock must be strong enough for the cavern to be stable such as igneous (granite, diorite.), metamorphic (gneiss, schists, hornfels) and even sedimentary rocks (sandstone, limestone, chalk, shale). Underground excavation can be performed using drilling and blasting cycle with the stages taken. Firstly by excavating the benches and next horizontal drilling is carried for the leveling of smooth contour on the crown. Depending on the methods adopted horizontal or vertical drilling can be carried based upon the execution of the work. Different types of construction involve for access of tunnels like providing the support to the rock which is guided by the concrete plugs to shut the cavern, where water curtain tunnel are from the drilled curtain bored holes and the water curtain tunnel is filled with water after being shut. For the stages of excavation necessary steps to be taken which is most important like surveying, drilling holes, charging of blast holes, demuckling, installation of shotcrete, ventilation and excavation face.

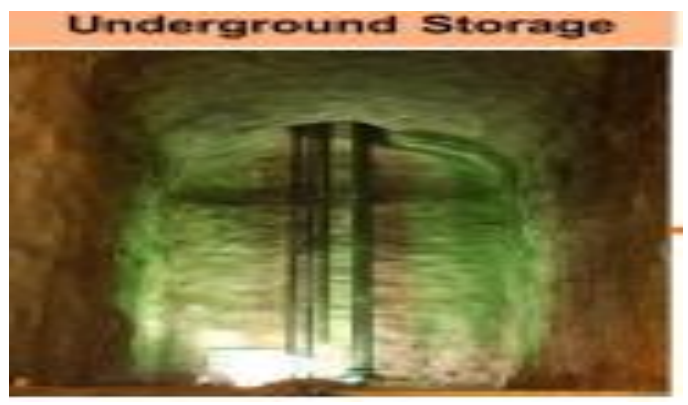

Fig. 1: the lined rock cavern system for storing [1]

\section{Background}

Several past attempts are studied to understand background of the present problem and the scope the study is worked out from the research gap identified.

\section{A. Literature review}

The Lined Rock Cavern (LRC) hypothesis was studied successfully in the pilot plant of Grängesberg between 1988 1992 (e.g., Stille et al. [1994]).

Congenitally, the underground storage is in expensive than inground storage tank [3]. However, the cost of underground storage is highly expensive as competitive as compared to in ground storage tank and slab heating systems and fire water systems are not needed or it can be also reduced[1,5]. It has been noticed that crude oil storage by Oil Company, the cost of operation storage is $63 \%$ less than in ground tank [4], and also there should not be any small galleries present in between because of their poor capacity. Geometrical surveys observed that underground storage which is in the model of gallery of $20 \times 30 \mathrm{~m}$ (width to height) in $\mathrm{c} / \mathrm{s}$ is most successful [2]. As many lining materials of plastic has been tested in the laboratory including PVC, PE, butyl. As compare to the studies of PVC and LDPE are the best capable than HDPE. As these materials are workable and to be applied on uneven surfaces. It is although known that some of the natural gases may be soften the plastic materials and for the long term it takes time and cannot be undertaken. For the long term the PE can be considered as they have chemically stabled and impervious [6,7].

\section{B. Scope of the study}

- From the scope it has been observed that very few studies are addressed on the rock lined cavern.

- Plastic analysis is not addressed so far.

- It is found that it is very difficult to get the design parameters of the rock which are realistic, hence some set 
of these parameters are considered as per the theoretical aspects.

- It is common practice that the suitable site for rock cavern is always the vicinity of the tunnel.

- Considering the above gap in literature the linear and plastic analysis of the rock underground cavern is analyzed located near the tunnel and combined analysis is carried out for the static load condition.

\section{Numerical Modelling}

\section{Numerical model}

The numerical model of the cavern and the tunnel is developed by using Phase 2 FE tool. The analysis is carried out for the set of engineering properties of rocks considered on the basis of theoretical understanding of the rock properties.

Table 1: Rock properties considered

\begin{tabular}{|l|l|l|l|l|l|l|l|}
\hline Rock type & RMR & $\begin{array}{c}\sigma_{\mathrm{ci}} \\
\mathrm{MPa}\end{array}$ & $\mathrm{m}_{\mathrm{b}}$ & $\mathrm{s}$ & $\begin{array}{l}\mathrm{C} \\
\mathrm{MPa}\end{array}$ & $\begin{array}{l}\Phi \\
\text { degrees }\end{array}$ & $\begin{array}{c}\text { E' } \\
\mathrm{GPa}\end{array}$ \\
\hline $\begin{array}{l}\text { Jointed } \\
\text { Sandstone }\end{array}$ & $\begin{array}{l}63- \\
75\end{array}$ & 100 & 4.3 & 0.02 & 3.8 & 50 & $\begin{array}{c}2.7- \\
5.6\end{array}$ \\
\hline $\begin{array}{l}\text { Bedded } \\
\text { sandstone }\end{array}$ & $\begin{array}{l}56- \\
60\end{array}$ & 100 & 1.5 & 0.002 & 3.3 & 45 & $\begin{array}{c}3.3- \\
15\end{array}$ \\
\hline $\begin{array}{l}\text { Faults or } \\
\text { shear zones }\end{array}$ & 33 & 46 & 0.64 & 0.0002 & 0.2 & 40 & 2 \\
\hline
\end{tabular}

The Constant field stress option can be used for the modelling of deep excavations as gravitational stress gradient is negligible across the height. A Constant field stress is defined by two inplane principal stresses ( $\sigma 1$ and $\sigma 3$ ), and an angle which defines the in-plane stress orientation. The out-of-plane principal stress $(\sigma \mathrm{z})$ is also required. Range of horizontal to vertical in situ stress ratios of 0.8 , i.e., $\sigma 3=0.8^{*} \sigma 1$ Out of plane principal stress $(\sigma \mathrm{z})$ is assumed to me $0.9^{*} \sigma 1$. Used to separate the stresses which are induced in the load in the middle of any stages of the test rather by relating the whole stress in the beginning stages as this gives a initial stress load, as excavation execution.

This allows the user to gradually apply the field stress load, as excavation progresses. A typical use of Load Splitting is to simulate the 3D effect using a 2D model. With next stage the model is done for excavating and installation of the bolts simultaneously. This stage is followed by the liner application. The properties of bolts and liner are mentioned below figure.

\begin{tabular}{|c|c|c|c|}
\hline Bolt name & Strands & Liner & steel lining \\
\hline \begin{tabular}{|l} 
Bolt Type \\
Diameter
\end{tabular} & $\begin{array}{l}\text { Fully bonded bolt } \\
25 \mathrm{~mm}\end{array}$ & Liner Type & Standard Beam \\
\hline Young's modulus & $200000 \mathrm{MPa}$ & Formulation & Timoshenko \\
\hline Tensile capacity & $0.2 \mathrm{MN}$ & Thickness & $0.015 \mathrm{~m}$ \\
\hline $\begin{array}{l}\text { Residual Tensile } \\
\text { capacity }\end{array}$ & $0.2 \mathrm{MN}$ & \multicolumn{2}{|l|}{ Elastic Properties } \\
\hline Pre-tensioning & $0 \mathrm{MN}$ & Young's modulus & $200000 \mathrm{MPa}$ \\
\hline Pre-tensioning force & $\begin{array}{l}\text { Constant in install } \\
\text { stage }\end{array}$ & Poisson's ratio & 0.3 \\
\hline \begin{tabular}{|l|} 
Out-of-plane spacing \\
Allow Joints to Shear \\
Bolt \\
\end{tabular} & $1 \mathrm{~m}$ & & \\
\hline
\end{tabular}

Fig. 2: Properties of bolt and liner

As per the different construction stages the model is developed. Fig 3 shows the stage FE model of the cavern and the tunnel. Also final model is assessed for static forces.
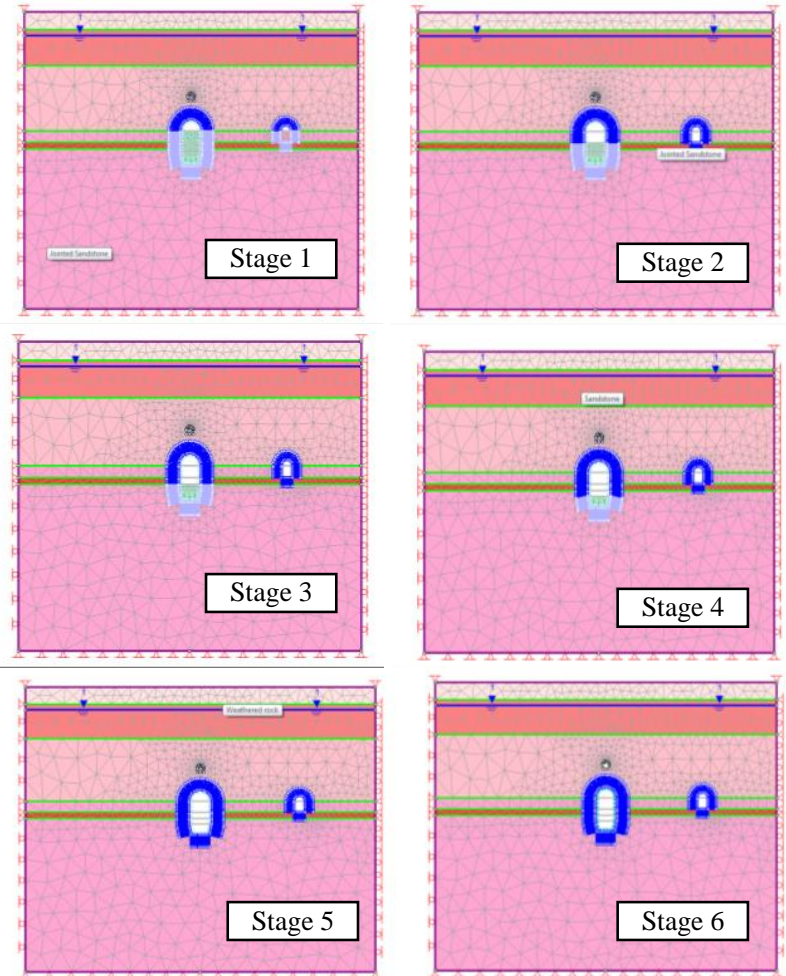

Fig. 3: Staged FE model of Cavern and Tunnel

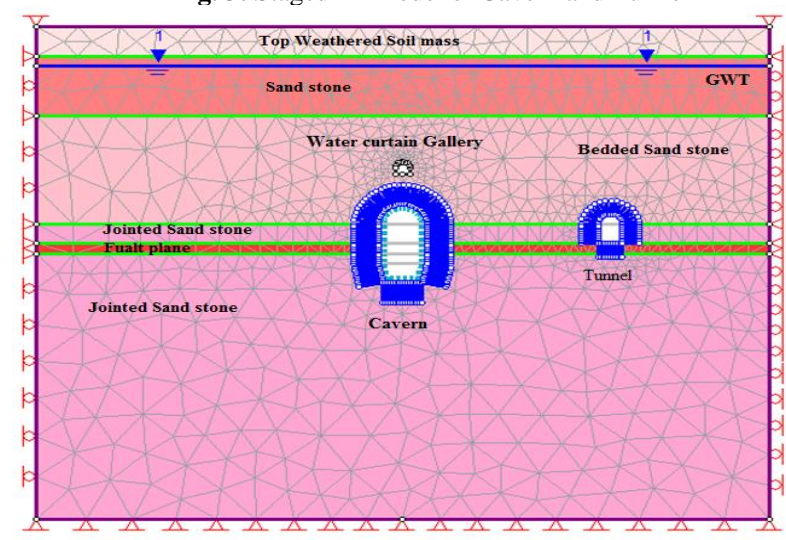

Fig. 3: Final FE model of Cavern and Tunnel

\section{4. result and discussion}

In linear analysis the material is assumed to have unlimited strength (i.e. it will not yield or fail). The material response will be linear elastic, regardless of the stress magnitude. For plastic Nonlinear analysis the material can yield and exhibit non-linear stressstrain behaviour, if the stress exceeds the strength envelope. For Mohr-Coulomb, Hook-Brown and Drucker-Prager material models, we specify peak and residual strength parameters. Residual strength will be applied if the peak strength is exceeded. If residual = peak, this defines an elastic-perfectly plastic material. If residual strength $=0$ this defines a brittle material. The deformed shape of cavern and tunnel is studied in the figure 4 for linear (4a) and plastic analysis (4b)

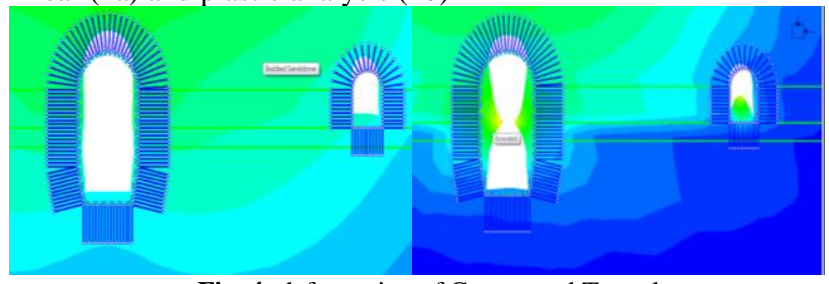

Fig. 4: deformation of Cavern and Tunnel 
The deformation vectors are studied in Fig. 5. It is clear that the soil below the cavern and above the caverns shows different stress conditions. The soil stresses below the caverns is much higher than the soil stresses above the cavern. Same observation is done for the tunnel.

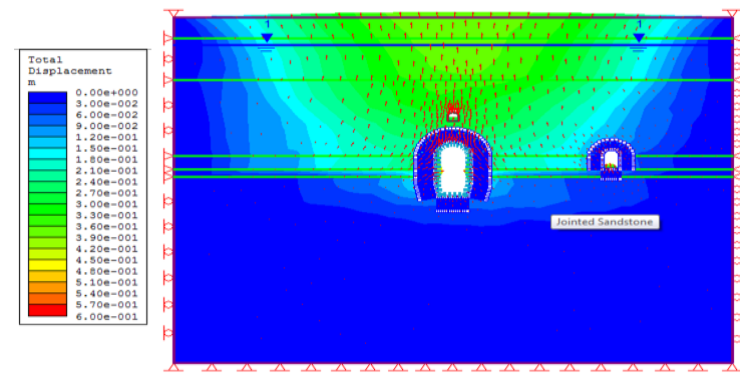

Fig. 5: Deformation vector in the model

Principal stress along cavern boundary is observed as this may be the critical area where different material interfaces are exists. The comparison is carried out for both elastic and plastic analysis. It has been observed that the elastic stresses are much higher up to half of the height of the cavern and for upper height the both elastic and plastic principal stresses and almost same (Fig. 6).

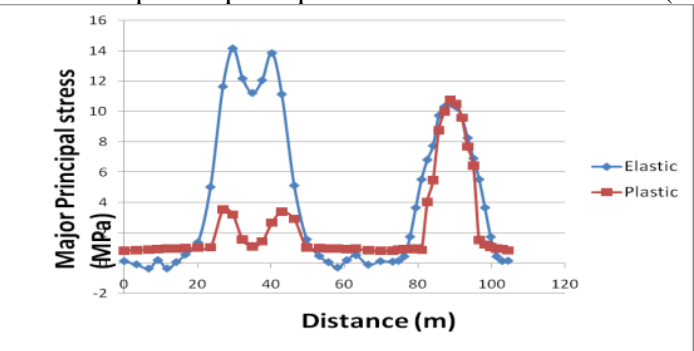

Fig. 6: Principal stress at the cavern boundary

\section{Conclusion}

Total maximum displacement has been increased in Non-linear analysis than in Elastic Analysis as it could enter into the nonlinear state.

Stress on the Cavern wall and strain of particles have been decreased in Non-linear analysis.

It is observed that strength factor is more that 1 in Non linear analysis.

That indicates that Cavern is more stable in Non-linear analysis, where as in Elastic analysis strength factor at some distances is less than 1 which not suitable to take the loads.

\section{References}

[1] SKEC, Geostock, and Saipem: "Taean LNG Receiving Terminal Project PreFeasibility Study Report", 2007.

[2] H.Y. Kim, S.W. Woo, D.H. Lee, J. Cho, "Economical and Technical Challenges in Lined Rock Cavern LNG Storage System", AIChE Spring Meeting, Tempa, USA, 2009

[3] SKEC, Geostock, and Saipem: "Proceedings of International Symposium on LNG Storage in Line Rock Caverns", Seoul, Korea, 2004.

[4] S.K. Chung, E.S. Park, K.C. Han, "Feasibility study of underground LNG storage system in rock cavern", presented at the11th ACUUS Conference, Athens, Greece, 2007.

[5] European Norm 14620, "Design and manufacture of site built, vertical, cylindrical, flat-bottomed steel tanks for the storage of refrigerated, liquefied gases with operating temperatures between 0 ${ }^{\circ} \mathrm{C}$ and $-165^{\circ} \mathrm{C} ", 2006$

[6] Brown, E. T., J. W. Bray, B. Ladanyi, and E. Hoek, 1983. "Ground Response Curves for Rock Tunnels," Journal of Geotechnical Engineering, ASCE 109, pp. 15-39.

[7] Harvey, R. C. and E. Burley, 1973. "Behaviour of Shallow Inclined Anchorages in Cohesionless Sand," Ground Engineering, Vol. 6, pp. $48-55$
[8] Stille, H., J. Johansson, and R. Sturk, 1994. "High Pressure Storage of Gas in Lined Rock Caverns - Results From Field Tests," Proceedings, EUROCK'94 International Conference, Delft, Balkema, Rotterdam 